\title{
Neovascular Glaucoma
}

\author{
Kurt Spiteri Cornish \\ Aberdeen Royal Infirmary \\ United Kingdom
}

\section{Introduction}

Neovascular glaucoma (NVG) is an intractable sight-threatening disease which is extremely difficult to manage and can lead to permanent visual loss. It occurs as a result of iris neovascularization also known as rubeosis iridis. Once the condition develops, early diagnosis and management is essential to minimize visual loss, thus better understanding of the causes and pathogenesis is essential. The objective of this chapter is to discuss the causes, pathogenesis and management options of NVG.

\section{Pathogenesis and pathology of NVG}

NVG is defined as rubeosis iridis or iris neovascularization (NVI) with secondary angleclosure glaucoma. It is a serious sequela of ischaemic eye diseases.

\subsection{Grading of iris neovascularization}

A grading system for NVI was proposed by Teich and Walsh (Teich, 1981), and is shown in Table 1.

\begin{tabular}{|c|l|}
\hline Grade & \\
\hline 0 & No iris neovascularization \\
\hline 1 & Less than 2 quadrants of NV at iris pupillary zone \\
\hline 2 & More than 2 quadrants of NV at iris pupillary zone \\
\hline 3 & $\begin{array}{l}\text { Grade } 2+\text { less than } 3 \text { quadrants of NV at iris ciliary zone and/or } \\
\text { ectropion uveae }\end{array}$ \\
\hline 4 & More than 3 quadrants of NV at iris ciliary zone and/or ectropion uveae \\
\hline
\end{tabular}

Table 1. Grading of NVI (Teich, 1981)

\subsection{Pathogenesis of NVG}

Retinal hypoxia is central in the pathogenesis of NVG. Ischaemia triggers release of factors that both inhibit and promote neovascularization (Brown, 1984), but greater concentrations of the former result in rubeosis. Such vasoproliferative factors include vascular endothelial growth factor (VEGF), fibroblast growth factor (FGF) and others. Intraocular concentrations of VEGF were found to be increased in patients with active proliferative diabetic retinopathy (PDR), central retinal vein occlusion (CRVO) and retinopathy of prematurity 
(ROP) (Aeillo, 1994; Malecaze, 1994; Adamis, 1994). VEGF was subsequently implicated in the pathogenesis of choroidal neovascularization in age-related macular degeneration. A close temporal correlation between aqueous VEGF and degree of iris neovascularization has been recorded (Hayreh, 2007). Infarcted retina, such as in central retinal artery occlusion (CRAO) does not cause production of VEGF or other growth factors, and thus is not associated with a risk of neovascularization and NVG.

VEGF is an endothelial cell specific mitogen, and is synthesized by several types of retinal cells, the primary source being Muller cells. Once VEGF is released, it causes rubeosis if it reaches the iris and angle; something which happens when the lens is removed, especially if the posterior capsule is breached (Rice, 1983). VEGF is also secreted by hypoxic retinoblastoma, causing rubeosis irides in eyes with the tumour (Pe'er, 1997).

The disease develops in 3 stages:

Neovascularization of the iris (NVI) : tiny tufts of vessels grow on the anterior surface of the iris, starting in most cases, but not invariably, at the pupillary border in many cases as that is the site of maximal turnover of aqueous containing growth factors. These vessels form before pressure rises.

Secondary open angle glaucoma (SOAG): The NVI extend to involve the angle, and are accompanied by fibrosis, invisible on gonioscopy, blocking the trabecular meshwork and causing ocular hypertension, and SOAG. Neovascular tissue found in the trabecular spaces might be one of the factors responsible for intraocular pressure elevation in eyes with neovascular glaucoma (Kubota, 1996).

Secondary angle closure glaucoma (SACG): Myofibroblasts within the fibrovascular tissue proliferate and contract, forming peripheral anterior synechiae (PAS), and secondary angle closure, with resulting intra-ocular pressure rise.

Animal experimental models have demonstrated the presence of inflammatory cells in the iris stroma, epithelium and on the surface of the fibroneovascular membrane during NVI formation (Hjelmeland, 1992). The active role of inflammation in the condition is further confirmed by the presence of NVG in non-ischaemic inflammatory eye diseases including Vogt-Koyanagi-Harada disease, endophthalmitis, chronic uveitis and Fuchs' heterochromic iridocyclitis (Feys, 1994; Norose 1994; Lappin 1997).

Interleukin-6 (IL-6) has also been implicated in the pathogenesis of NVG. Increased aqueous concentrations of IL-6 have been correlated temporally and spatially with the grade of iris NV in patients with NVG secondary to CRVO (Chen, 1999). IL-6 expression was shown to increase in rat retina after transient ischaemia (Hangai, 1996). Studies are required to investigate whether IL-6 levels can be used as predictors of NVG.

Transforming growth factor (TGF)-beta was also noted to be increased in the aqueous of eyes with NVG and might be implicated in formation and contraction of iris neovascular membranes (Yu, 2007).

\section{Causes of NVG}

The main cause of neovascular glaucoma is severe retinal ischaemia, as a result of which vasoproliferative growth factors are produced to attempt revascularization of the hypoxic areas. This process can result in neovascularization of the iris (NVI) and of the angle (NVA) of the anterior chamber, thus causing secondary glaucoma. Only $3 \%$ of cases of NVG are caused by inflammation without retinal ischaemia (Brown, 1984).

By far the commonest causes of NVG are proliferative diabetic retinopathy, ischaemic central retinal vein occlusion (CRVO) and ocular ischaemic syndrome. However, there are 
reports of other conditions which have been associated with NVG and they are shown in Table 2.

\begin{tabular}{|} 
Diabetic Retinopathy \\
Retinal Vascular Occlusive Diseases \\
Central Retinal Vein Occlusion \\
Ischaemic Hemiretinal Vein Occlusion \\
Ocular Ischaemic Syndrome \\
Carotid Artery Occlusive Disease \\
Takayasu's Syndrome \\
Carotid-Cavernous Fistula \\
Giant Cell Arteritis \\
Wyburn-Mason syndrome \\
Strabismus Surgery \\
Ocular Radiation \\
Tumours \\
Uveal Melanomas \\
Metastatic Choroidal Tumours \\
Medulloepithelioma \\
Retinoblastoma \\
Pigmented Ciliary Adenocarcinoma \\
Metastatic Malignant Lymphoma \\
Uveitis \\
Retinal Vasculitis \\
Coat's Disease \\
Eales' Disease \\
Sarcoidosis \\
X-linked Retinoschisis \\
Chronic Retinal Detachment \\
Retinopathy of Prematurity \\
Systemic Cryoglobulinaemia
\end{tabular}

Table 2. Causes of Neovascular Glaucoma

\subsection{Diabetic retinopathy}

It is well known that neovascular glaucoma can arise in diabetic retinopathy. In eyes with proliferative diabetic retinopathy, the incidence of NVI is 65\% (Ohrt, 1961). The causative mechanism that is widely accepted is the presence of severe diffuse retinal ischaemia, which in turn promotes production of neovascular growth factors.

In one study, retinal non-perfusion was classified according to the area of retina involved in the midperiphery (Hamanaka, 2001). Area of retinal non-perfusion greater than $50 \%$ was a statistically significant risk factor for NVA. Eyes with new vessels at the optic disc (NVD) also have increased risk of NVA. As the NVA results in anterior synechiae and secondary closure of the angle, advancement of NVA therefore increases the risk of high 
intra-ocular pressure (IOP). This, however, also depends on the individual anatomy of the trabecular meshwork in the individual's angle, as the elevation of IOP depends on the amount of space left in the trabecular meshwork following NVA and anterior synechial formation.

Diabetic iridopathy has been graded by the extent of rubeosis (Laatikainen, 1979):

Grade I. Peripupillary vessel dilatations (dilated leaking vessels around the pupil)

Grade II. Early neovascularization in the angle (small, irregular arborizing superficial newly formed vessels in the angle, associated with an open angle).

Grade III. Prominent rubeosis with or without NVG (vessels grown out of the angle, affecting more of the iris surface

Grade IV. Florid rubeosis (associated with angle closure)

\subsection{Retinal vascular occlusive diseases}

NVG is a complication of ischaemic CRVO (Hayreh, 1982). Distinction between ischaemic and non-ischaemic RVO is based on a number of criteria (Hayreh, 1990; The Central Retinal Vein Occlusion Group, 1995). Visual acuity tends to be worse than 6/120 in ischaemic CRVO, with a relative afferent pupillary defect (RAPD) present and a b-wave amplitude of less than $60 \%$ on electroretinography (ERG). The information provided by FFA is limited. Studies have shown that eyes with 75 disc diameters or more of ischaemia (capillary dropout) are most at risk of resulting in neovascularization, the maximum risk being in the first 7-8 months from diagnosis. Like CRVO, NVG is also a complication of ischaemic hemicentral retinal vein occlusion (HCRVO), occurring in $3 \%$ of cases (Hayreh, 1982).

\subsection{Ocular Ischaemic syndrome}

Ocular ischaemic syndrome (OIS) is caused by reduction of blood flow to the eyeball and manifests itself as anterior and/or posterior segment ischaemia. Most cases are caused by carotid artery occlusive disease (CAOD), which accounts for $13 \%$ of all cases of NVG. It is diagnosed with carotid Doppler ultrasound and carotid angiography. Apart from OIS, CAOD can also cause brain ischaemia (transient ischaemic attacks or cerebral vascular accidents) and embolic retinal artery occlusions. However, OIS can be caused by other diseases, including Takayasu's syndrome, Carotid-cavernous fistula, giant cell arteritis, Wyburn-Mason syndrome and iatrogenic causes such as strabismus surgery (Saunders, 1994). An important differentiating feature among OIS, CRVO and diabetic retinopathy is low retinal arterial pressure (Mendrinos, 2010) and this can be tested in clinical practice by light digital pressure on the globe, which induces retinal artery pulsations in eyes with OIS. It is also important to note that pain in OIS is not always attributable to NVG, as ischaemic pain occurs in up to $40 \%$ of eyes with OIS.

\subsection{Ocular radiation}

It is well recognized that radiation for ocular and orbital lesions can lead to NVG, and this is due to radiation retinopathy. This can occur as a result of exposure to any source of radiation, including external beam and plaque radiotherapy. For instance, radiation retinopathy has been reported to occur in $10-63 \%$ of eyes treated for choroidal melanoma with plaque radiotherapy (Wen, 2009; Foss, 1997). Apart from choroidal melanomas, 
radiation has been used for a number of lesions, including iris melanomas, choroidal metastatic tumours, optic nerve glioma, retinoblastoma, orbital lymphoma and nasal malignancies. The ensuing retinal ischaemia can lead to NVG.

\subsection{Tumours}

NVG has been associated with choroidal melanomas, the mechanism being attributed to release of angiogenic factors, serous retinal detachment with secondary retinal ischaemia, retinal vascular occlusion by direct invasion by the tumour, inflammation and radiation retinopathy (Lee, 2001). Reports of other tumours causing NVG have been documented, including ring melanoma of anterior uvea, medulloepithelioma, choroidal haemangioma, metastatic cutaneous melanoma, retinoblastoma, pigmented ciliary adenocarcinoma and metastatic malignant lymphoma (Hayreh, 2007; Schalenbourg, 2008).

\subsection{Other Causes}

NVG has also been documented in cases of retinal vasculitis (Salmon, 2000), Coat's disease (Shields, 2007; Shields, 2001), Eales disease (Atmaca, 2002), sarcoidosis (Gaskin, 2005), Xlinked retinoschisis (Rosenfeld, 1998), uveitis, chronic retinal detachment, retinopathy of prematurity and systemic conditions such as cryoglobulinaemia (Telander, 2006) and Neurofibromatosis I (Elgi, 2010). NVG can occur in anterior, posterior or panuveitis and can be due to the inflammation itself, anterior segment ischaemia, or the underlying causative condition such as Crohn's disease. Uveitis in the presence of chronic iridocyclitis, Fuch's uveitis syndrome, scleritis and carotid occlusive disease (OIS) has been especially implicated in NVG (Perry, 1975; Coppeto, 1985).

\section{Diagnosis of NVG}

A high index of suspicion in context of the above diseases is required to diagnose early NVG, where intra-ocular pressure is not elevated and only subtle signs are present. In most cases, neovascularization of the iris starts as fine vessels at the pupillary margin and can be easy to miss. Examination of the iris and gonioscopy with an undilated pupil is essential. Careful gonioscopy is required to detect NVA and anterior synechiae. The CRVO study found that $6 \%$ of eyes with ischaemic CRVO had NVA without iris new vessels (CRVO Study Group, 1993). In fact, undilated gonioscopy should be performed on all patients at risk of developing NVG. Fluorescein iris angiography can be useful in differentiating iris neovascularization from normal iris vessels as the latter do not leak fluorescein. Anterior chamber cells and flare can accompany rubeosis due to leakage of the abnormal vessels, and can be misdiagnosed as anterior uveitis.

Studies on pupil reactions in patients with CRVO revealed that a relative afferent pupillary defect of $0.6 \log$ units was $83 \%$ sensitive and $70 \%$ specific in predicting development of rubeosis in patients with CRVO (Bloom, 1993). However, further studies on pupil examination in disease processes are needed.

Fundus fluorescein angiography (FFA) is important in illustrating the extent and area of retinal ischaemia. Electroretinogram (ERG) can help in diagnosing retinal ischaemia. More recently, anterior chamber optical coherence tomography (AS-OCT) and ultrasound biomicroscopy (UBM) illustrates anterior segment structures in great detail and are being used more frequently in diagnosing and staging of the disease. 
Ultimately, a high index of suspicion and undilated gonioscopy is central in the diagnosis of neovascular glaucoma.

\section{Management}

Management of neovascular glaucoma can be divided into treatment of the underlying disease process responsible for rubeosis, and management of the elevated intra-ocular pressure which develops.

\subsection{Treatment of underlying disease}

Evidence for treatment of diabetic retinopathy is based on various studies. More specifically to NVG, the Diabetic Retinopathy Study (DRS) determined that laser photocoagulation reduces the risk of severe visual loss by $50 \%$ compared with no treatment (The Diabetic Retinopathy Study Research Group, 1981), and is the treatment of choice for prevention of NVG in diabetic eyes. Ohnishi et al documented regression of rubeosis in $68 \%$ and normalization of intra-ocular pressure in $42 \%$ of diabetic patients treated with PRP (Ohnishi, 1994). The importance of applying an adequate dose of PRP has been demonstrated (Simmons, 1980). As well as laser treatment, the Diabetes Control and Complications trial (DCCT) showed that lowering blood glucose reduces risk of visual loss due to retinopathy by 76\% (The Diabetes Control and Complications Trial Research Group, 1993).

A multicentre prospective clinical trial by the Central Vein Occlusion Study (CVOS) group investigated the role of pan-retinal photocoagulation (PRP) in ischaemic CRVO (The Central Vein Occlusion Study Group, 1995). The gold-standard management of ischaemic CRVO, as derived from this study, is that of prompt PRP of eyes which develop two clock hours of iris/angle neovascularization. This is still a matter of controversy, as pointed out by Hayreh SS et al recently, stating that "approximately one-third of the eyes with iris NV and treated with PRP would never have developed NVG" (Hayreh, 1983). It is recommended that PRP is performed at the first sign of rubeosis (Hayreh, 1990b; Magargal, 1982).

Management of ocular ischaemic syndrome is difficult. PRP cannot be used in OIS. This is supported by the fact that retinal capillary non-perfusion has not been shown to occur on fundus fluorescein angiography in OIS (Mizener, 1997). In patients with neurological symptoms, there is an indication for carotid endarterectomy, which may lead to regression of new vessels. However, it can also paradoxically cause an intraocular pressure rise by restoring normal aqueous production. Nocturnal systemic hypotension should be avoided as it can precipitate ischaemic visual loss (Mizener, 1997), thus nightime anti-hypertensives should be avoided, and, when possible, beta-blocker drops are ideally not used for IOP control.

Laser photocoagulation of areas of retinal nonperfusion has been advocated also in the treatment and/or prophylaxis of radiation retinopathy (Hykin, 1998). Single treatment with laser may, however, not be enough, and further laser might be needed at a later stage. Close follow-up is therefore recommended. As plaque brachytherapy creates a predictable zone of ischaemia, treating this zone with laser photocoagulation may prevent progression of radiation retinopathy (Finger, 2005). It has been hypothesized that this prevents ischaemic tissue from producing VEGF and cytokines responsible for causing new vessel proliferation, but further studies are required with respect to prophylactic treatment (Wen, 2009).

Treatment of any ocular inflammatory disease consists of topical steroids and mydriatics, but may require systemic corticosteroids and/or immunosuppression, together with management of any underlying systemic disease. 


\subsection{Treatment of high IOP in NVG}

Unfortunately, the current literature on neovascular glaucoma has only few articles that provide strong evidence in support of certain therapeutic recommendations (Sivak-Callcott, 2001).

\subsubsection{Medical therapy}

Medical therapy is the first step in managing NVG by suppressing aqueous production, hence decreasing intraocular pressure. Beta-blockers, topical and oral carbonic anhydrase inhibitors and alpha-2-adrenergic agonists are used, whereas prostaglandin analogues, which work by increasing uveal outflow, are not useful if the angle is closed. Topical corticosteroids are used concurrently to treat any associated inflammation. Atropine may be used for its cycloplegic effect in addition to increasing uveoscleral outflow. Pilocarpine and anticholinergic agents are contra-indicated as they increase inflammation, cause miosis, worsen synechial angle closure and decrease uveoscleral outflow. In most cases of NVG, medical therapy is not enough to control IOP and prevent visual loss.

\subsubsection{Glaucoma filtering surgery}

Glaucoma filtering surgery for NVG, in the form of trabeculectomy, is often unsuccessful (Mietz, 1999). This has therefore been augmented with antimetabolites, mitomycin C (MMC) or 5-fluorouracil (5-FU). They help modulate the wound healing process to lessen scar formation around the scleral flap in trabeculectomy, which is the commonest cause of surgical failure. Both MMC and 5-FU have been shown to improve the success rate of trabeculectomy in eyes with NVG (Tsai, 1995; Hyung, 2001). Previous studies suggest that the use of MMC is superior to 5-FU in the surgical management of refractory glaucoma (Katz, 1995; Sisto, 2007; Skuta, 1992). However, the prognosis of augmented trabeculectomy remains poor in NVG (Sisto, 2007), and a success rate of $28 \%$ at 5 years has been reported after filtering surgery with 5-FU for NVG (Tsai, 1995). Poor prognostic factors for MMCaugmented trabeculectomy in NVG include young age (less than 50 years), previous vitrectomy (which may be due to conjunctival scarring, intra-ocular inflammation and increased diffusion of vasoproliferative factors) (Takihara, 2009; Kiuchi, 2006), presence of pseudophakia (Al Obeidan, 2008) and presence of proliferative retinal membranes or retinal detachment (Kiuchi, 2006). Adequate pan-retinal photocoagulation performed prior to trabeculectomy has been shown to improve the effectiveness of surgery (Al Obeidan, 2008). There have also been reports of MMC-trabeculectomy combined with amniotic membrane grafts under the scleral flap for improved intra-ocular pressure control and increased surgical success (Sheha, 2008; Fujishima, 1998; Bruno, 2006), due to its anti-inflammatory, anti-fibrotic and anti-angiogenic properties.

\subsubsection{Anti-VEGF therapy}

Anti-VEGF therapy (bevacizumab) has been successfully used as adjunctive therapy in addition to augmented trabeculectomy (Kotecha, 2011; Spiteri Cornish 2009; Alkawas, 2010; Fakhraie, 2010; Saito, 2010). As discussed above, VEGF has a key role in the pathogenesis of NVG. The role of anti-VEGF therapy in neovascular glaucoma has been described as being twofold - control of the neovascular process, and modulation of the healing process at the trabeculectomy site (Spiteri Cornish, 2009). However, anti-VEGF cannot be used alone to treat NVG, but is used only as an adjunct to PRP, medical therapy and surgery. 
Endothelial cells in rubeotic vessels are different from normal iris vessels (Williams, 1988; Miller, 1984) and one of the effects of VEGF on new vessel formation is mediated through formation of fenestrations, thus causing vascular hyperpermeability. A single dose of intravitreal bevacizumab (Avastin ${ }^{\circledR}$, Genentech, South San Francisco, CA, USA) has been shown to induce vascular endothelial cell apoptosis in immature vessels and induce maturation of premature vessels characterized by disappearance of fenestrations and an increase in pericyte coverage (Kohno, 2010). Further studies confirm that intravitreal injection of bevacizumab reduces vascular permeability (Ishibashi, 2010). The characteristic hyperpermeability of vessels formed in pathologic angiogenesis may be responsible for the ocular pain in NVG. This is likely the result of increased presence of inflammatory mediators in the eye. A recent study suggests that intra-vitreal bevacizumab can be used to control pain in refractory NVG, despite a modest intra-ocular pressure reduction (Kotecha, 2011). This confirms previous observations of anti-VEGF resulting in rapid relief of symptoms in NVG (Iliev, 2006).

Studies show that anti-VEGF also reduced scar formation during wound healing, showing that VEGF strongly influenced scar tissue formation (Wilgus, 2008; Li, 2009; Nissen, 1998). The most important cause of failure of trabeculectomy is persistent inflammation followed by fibrosis at the site of the scleral flap, preventing the formation of an adequate draining bleb (Vote, 2004).

Several case series report rapid regression of anterior segment neovascularization following an intra-vitreal injection of bevacizumab in NVG (Iliev, 2006; Moraczewski, 2009; Wakabayashi, 2008; Mason 2006b; Silva, 2006), and has been used in NVG secondary to diabetic retinopathy (Avery, 2006; Mason, 2006; Oshima, 2006), CRVO (Iliev, 2006) and ocular tumours (Yeung, 2010). However, duration of action of bevacizumab is about four weeks and multiple injections may be necessary (Fakhraie, 2010).

Based on the case series and small studies in literature, pre-operative intravitreal bevacizumab combined with MMC-augmented trabeculectomy seems to be an effective method of controlling intra-ocular pressure and pain in NVG. It has also been observed that prognosis is better if there is less delay between diagnosis and treatment (Fakhraie, 2010). The long-term efficacy of this therapy is however unknown and repeat injections may be required, much like in age-related macular degeneration. Randomized-controlled trials are needed to further assess the efficacy and safety of this treatment option for NVG.

\subsubsection{Valve implant surgery}

Aqueous tube shunts are used in NVG when there is a high risk of failure from conventional filtering surgery. Various devices have been described, including Molteno implant, Baerveldt implant, Ahmed valve, Schocket tube and Krupin valve.

The Ahmed valve was designed to prevent post-operative hypotony, and is theoretically open only at intraocular pressures of more than $8 \mathrm{mmHg}$. Complications associated with it include hypotony, anterior chamber shallowing, choroidal detachments, hyphaema, tube malposition or occlusion, and restrictive ocular motility. Hyphaema is the most prevalent complication, occurring in $14 \%$ of cases in one study (Kim, 2003). The tube can be placed in the anterior chamber, sulcus or vitreous cavity (Rush, 2009; Netland, 2009). The Ahmed Glaucoma Valve was shown to be successful in lowering IOP in the short and intermediate term in NVG, but in the long term, the implant failed to control IOP (Yalvac, 2007), and 
success rate with AVG in NVG is statistically significantly lower than other types of glaucoma (Netland, 2009).

Similarly, the Molteno implant was shown to reduce IOP up to 5 years in a prospective study (Every, 2006; Broadway, 2001), the success rate progressively decreasing thereafter (Yalvac 2007; Every, 2006). In the largest study of Molteno implants in NVG, successful IOP control occurred in $62 \%$ of eyes at 1 year and $10.3 \%$ at 5 years (Mermoud, 1993). Prognosis remained poor, and loss of vision occurred in $48 \%$ and phthisis in $18 \%$, the worst off being NVG secondary to CRVO.

Baerveldt implants are seen as an effective and safe treatment for intermediate-term IOP control in patients with NVG (Sidoti, 1995; Krishna, 2001). Twelve-month IOP success rates was $79 \%$ (compared to $56 \%$ at 18 months) in one report (Sidoti, 1995). However, many patients lose visual acuity despite IOP control because of the severity of their underlying retinal disease. Baerveldt implants have also been combined with pars-plana vitrectomy, allowing management of vitreo-retinal pathology at the same time, such as endophotocoagulation, removal of any media opacities and repair of retinal detachment. Results were encouraging in documented case series of pars plana Baerveldt implant (PPBI), with success rates for IOP control of 91\% (Luttrull, 1995) and 94\% (Chalam, 2002), and preservation of visual acuity in $91 \%$. Complications of anterior chamber placed tubes are avoided, including endothelial touch, shallow anterior chambers, uveitis, cataract, tube obstruction and hyphaema. This was also seen with Ahmed valves (Faghihi, 2007) and Molteno implants (Lloyd, 1991) where the tube was implanted in the vitreous cavity and the procedure combined with a pars-plana vitrectomy, with good results. However, posterior segment complications such as retinal detachment, obstruction of the tube with vitreous, epiretinal membrane and cystoid macular oedema means that the procedure should be used in selected cases only, namely glaucomatous eyes with shallow anterior chambers and with associated vitreoretinal pathology such as vitreous haemorrhage (Faghihi, 2007; Hong, 2005).

A systematic review of literature on glaucoma drainage devices concluded that Molteno implant, Baerveldt implant, Ahmed valve and Krupin valve showed no statistically significant difference in IOP change or overall success rate (Hong, 2005).

\subsubsection{Cycloablative treatment}

Cyclodestructive procedures are used as a last resort in NVG, to reduce intra-ocular pressure. Various methods have been used with the sole purpose of partially destroying the ciliary body, hence reducing aqueous production. Cyclodiathermy was replaced by cyclocryotherapy, which was then superseded by laser ablative treatment using Nd:YAG or diode laser using a transscleral approach. Cyclocryotherapy is associated with more pain and is therefore less tolerated than laser therapy (Hayreh, 2007), and may be associated with a higher complication rate (Goldenberg-Cohen, 2005; Silvak-Callcott, 2001). Sympathetic ophthalmia, retinal detachment, anterior segment ischaemia and phthisis bulbi have been reported with cyclocyrotherapy.

Diode laser cyclophotocoagulation (DCPC) is very effective in reducing intra-ocular pressure in refractory glaucoma, with single or repeated treatments (Iliev, 2007), with the overall success rate quoted as $70 \%$, with a $35-55 \%$ reduction in IOP (Bloom, 1997; Noureddin, 2006; Murphy, 2003; Ansari, 2007). This is comparable to intraocular pressure reduction produced by Ahmed Glaucoma Valve (AGV) implantation in NVG (Yildirim, 2009). It is more effective than continuous wave YAG laser, and equivalent to free running 
Nd:YAG laser (Oguri, 1998). DCPC combined with PRP could be more effective than DCPC alone (Rehak, 1994). Micropulse DCPCis comparable to conventional cyclodiode laser. However, there are complications associated with cyclophotocoagulation therapy, hypotony occurring in 15-20\% of cases (Murphy, 2003; Iliev 2007). Other complications include loss of vision, corneal decompensation, necrotizing scleritis, hyphaema and phthisis bulbi (YapVeloso, 1998; Shen, 2004; Leszczyńsk, 2008; Hampton, 1990).

Ciliary body excision has been documented, but is associated with very high complication rates including vitreous haemorrhages, vitreous loss, expulsive haemorrhages, hypotony, retinal detachment and phthisis bulbi (Sautter, 1984).

Although cyclodiode ablation seems to be effective in reducing IOP in refractory NVG, its long term success rate has not been well described yet.

\subsubsection{Photodynamic Therapy (PDT)}

Photodynamic therapy with verteporfin recently has proven to be effective in partially obliterating anterior segment neovascularization in NVG secondary to ischaemic CRVO (Parodi, 2004; Parodi, 2005; Parodi, 2007). This had been previously proposed in animal experimental models (Packer, 1984; Miller, 1991; Husain, 1997). It was reported that PDT causes an overall IOP decrease of $39 \%$ (Parodi, 2005) and significant involution of iris and angle neovascularization (Parodi, 2007). It is postulated that up-regulation and release of proangiogenic factors in ischaemic CRVO has a temporary effect, and when angle and iris neovascularization are limited (in this case by PDT), this pro-angiogenic stimulus may gradually dissipate, and subsequent growth of new vessels is limited. Although encouraging, further studies are required to assess the role and efficacy of PDT in NVG.

\subsubsection{Management of the painful blind eye}

Neovascular glaucoma is a very difficult condition to manage, and visual outcome does not always follow IOP control due to the underlying ocular disease. Blindness can ensue, which may be very painful due to high intraocular pressure and inflammation. Keeping the eye comfortable requires topical corticosteroids, cycloplegics, cycloablation and even alcohol injection. The last resort is enucleation (or in some cases, evisceration). It is the duty of the ophthalmologist to remind the patient that the latter requires maintenance and compliance.

\subsection{Summary of treatment}

Clinical recommendations for diagnosis and treatment of NVG, based on an evidence-based systematic review, are listed in table 3 (Sivak-Callcott, 2001; Hayreh, 2007).

\begin{tabular}{|l|}
\hline Diagnosis of NVG \\
High level of suspicion about neovascularization (NV) in conditions at high risk \\
(diabetic retinopathy, ischaemic CRVO, ocular ischaemic syndrome, amongst \\
others) \\
Full ocular examination, especially undilated gonioscopy \\
Fundus fluorescein angiography may help identify areas of retinal ischaemia \\
Anterior segment fluorescein angiography may help identify neovascularization \\
Electroretinography may help estimate the risk of anterior segment NV. \\
Treatment of NVG \\
Treatment of underlying disease (see text)
\end{tabular}


Prompt medical treatment of elevated IOP and any ocular inflammation Glaucoma surgery to preserve vision if medical treatment insufficient (filtering surgery; valve implant surgery, with/without anti-VEGF)

Painful blind eyes are managed with topical corticosteroids, cycloplegics, cycloablation, and as a last resort, enucleation/evisceration

Table 3. Clinical recommendations for diagnosis and treatment of NVG

\section{Acknowledgements}

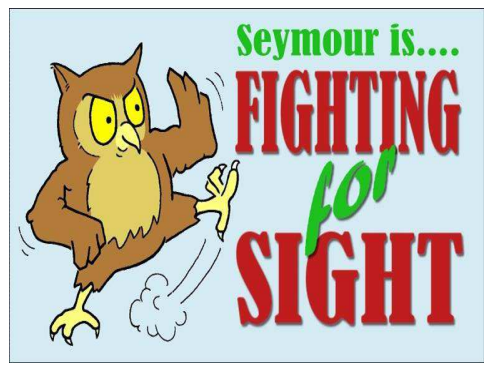

Fighting for Sight Aberdeen

\section{References}

Adamis, AP; Miller, JW; Bernal, MT, et al (1994). Increased vascular endothelial growth factor levels in the vitreous of eyes with proliferative diabetic retinopathy. Am J Ophthalmol. 118: 445-50.

Aiello, LP; Avery, RL; Arrigg, PG, et al (1994). Vascular endothelial growth factor in ocular fluid of patients with diabetic retinopathy and other retinal disorders. $N$ Eng J Med. 331: 1480-7.

Alkawas, AA; Shahien, EA; Hussein, AM. Management of neovascular glaucoma with panretinal photocoagulation, intravitreal bevacizumab, and subsequent trabeculectomy with mitomycin C. J Glaucoma. 19: 622-6.

Al Obeidan, SA; Osman, EA; Al-Amro, SA; Kangave, D; Abu El-Asrar, AM (2008). Full preoperative panretinal photocoagulation improves the outcome of trabeculectomy with mitomycin C for neovascular glaucoma. Eur J Ophthalmol. 18: 758-64.

Ansari, E; Gandhewar, J (2007). Long-term efficacy and visual acuity following transscleral diode laser photocoagulation in cases of refractory and nonrefractory glaucoma. Eye. 21: 936-40.

Atmaca, LS; Batioglu, F; Atmaca Sonmez, P (2002). A long-term follow-up of Eales' disease. Ocul Immunol Inflamm. 10: 213-21.

Avery, RL; Pearlman, J; Pieramici, DJ; et al (2006). Intravitreal bevacizumab (Avastin) in the treatment of proliferative diabetic retinopathy. Ophthalmology. 113: 1695, e1-e15.

Bloom, PA; Papakostopoulos, D; Gogolitsyn, Y, et al (1993). Clinical and infrared pupillometry in central retinal vein occlusion. $\mathrm{Br}$ J Ophthalmol. 77: 75-80. 
Bloom, PA; Tsai, JC; Sharma, K, et al (1997). Cyclodiode trans-scleral diode laser cyclophotocoagulation in the treatment of advanced refractory glaucoma. Ophthalmology. 104: 1508-19.

Broadway, DC; Lester, M; Schulzer, M; Douglas, GR (2001). Survival analysis for success of Molteno tube implants. Br. J Ophthalmol. 85: 689-95.

Brown, GC; Magargal, LE; Schachat, A; Shah, H (1984). Neovascular glaucoma. Etiologic considerations. Ophthalmology. 91: 315-20.

Bruno, CA; Elsengart, JA; Radenbaugh, PA, et al (2006). Subconjunctival placement of human amniotic membran e during high risk glaucoma filtration surgery. Ophthalmic Surg Lasers Imaging. 37: 190-7.

Chalam, KV; Gandham, S; Gupta, S; Tripathi, BJ; Tripathi, RC (2002). Pars plana modified Baerveldt implant versus neodymium:YAG cyclophotocoagulation in the management of neovascular glaucoma. Ophthalmic Surgery and Lasers. 33: 383-94.

Chen, KH; Wu, CC; Roy, S; Lee, SM; Liu, JH (1999). Increased interleukin-6 in aqueous humour of neovascular glaucoma. Invest Ophthalmol Vis Sci. 40: 2627-32.

Coppeto, JR; Wand, M; Bear, L; Sciarra, R (1985). Neovascular glaucoma and carotid artery obstructive disease. Am J Ophthalmol. 99: 567-70.

Diabetic Retinopathy Study Group (1981). The Diabetic Retinopathy Study Research Group: Photocoagulation treatment of proliferative diabetic retinopathy: Clinical application of Diabetic Retinopathy Study (DRS) findings. Diabetic Retinopathy Study (DRS) Report Number 8. Ophthalmol 88: 583-600.

Every, SG; Molteno, AC; Bevin, TH; Herbinson, P (2006). Long-term results of Molteno implant insertion in cases of neovascular glaucoma. Arch Opthalmol. 124: 355-60.

Elgin, U; Berker, N; Teke, MY; Simsek, T; Ozdal, P (2010). Unusual association of peripheral retinal ischemia-induced neovascular glaucoma and neurofibromatosis type $1 . J$ Pediatr Ophthalmol Strabismus. 47: e1-3.

Faghihi, H; Hajizadeh, F; Seyed-Farzad, M; Kadkhoda, A; Peyman, GA; Riazi-Esfahani, M (2007). Pars plana Ahmed valve implant and vitrectomy in the management of neovascular glaucoma. Ophthalmic Surg Lasers Imaging. 38: 292-300.

Fakhraie, G; Katz, LJ; Prasad, A; Eslami, Y; Sabour, S; Zarei, R; Moghimi, S (2010). Surgical outcomes of intravitreal bevacizumab and guarded filtration surgery in neovascular glaucoma. J Glaucoma. 19: 212-8.

Feys, J; Emond, JP; Salvanet-Bouccara, A; Dublanchet, A (1994). Interleukin-6 and other cytokines in the aqueous humour in uveitis and endophthalmitis. J Fr Ophthalmol. 17: 634-9.

Finger, PT; Kurli, M (2005). Laser photocoagulation for radiation retinopathy after ophthalmic plaque radiation therapy. Br J Ophthalmol. 89: 730-8.

Foss, AJE; Whelehan, I; Hungerford, JL, et al (1997). Predictive factors for the development of rubeosis following proton beam radiotheraphy for uveal melanoma. $\mathrm{Br} \mathrm{J}$ Ophthalmol. 81: 748-54.

Fujishima, H; Shimazaki, J; Shinozaki, N, et al (1998). Trabeculectomy with the use of amniotic membrane for uncontrolled glaucoma. Ophthalmic Surg Lasers. 29: 428-31.

Gaskin, BJ; Danesh-Meyer, HV (2005). Neovascular glaucoma and sarcoidosis. Eye. 19: 599601. 
Goldenberg-Cohen, N; Bahar, I; Ostashinski, M, et al (2005). Cyclocryotherapy versus transscleral diode laser cyclophotocoagulation for uncontrolled intraocular pressure. Ophthalmic Surg Lasers and Imaging. 36: 272-80.

Hamanaka, T; Akabane, N; Yajima, T; Takahashi, T; Tanabe, A (2001). Retinal ischemia and angle neovascularization in proliferative diabetic retinopathy. Am J Ophthalmol. 132: 648-58.

Hampton, C; Shields, MB; Miller, KN; Blasini, M (1990). Evaluation of a protocol for transscleral neodymium:YAG cyclophotocoagulation in one hundred patients. Ophthalmology. 97: 910-917.

Hangai, M; Yoshimura, N; Honda, Y (1996). Increased cytokine expression in rat retina following transient ischemia. Ophthalmic Res. 28: 248-54.

Hayreh, SS; Podhajsky, P (1982). Ocular neovascularization with retinal vascular occlusion II. Occurrence in central and branch retinal artery occlusion. Arch Ophthalmol. 100: 1585-96.

Hayreh, SS; Rojas, P, Podhajsky, P; Montague, P; Woolson, RF (1983). Ocular neovascularization with retinal vascular occlusion. Incidence of ocular neovascularization with retinal vein occlusion. Ophthalmology. 90: 488-506.

Hayreh, SS; Klugman, MR; Beri, M; Kimura, AE; Podhajsky, P (1990). Differentiation of ischemic from non-ischemic central retinal vein occlusion during the early acute phase. Graefes Arch Klin Exp. Ophthalmol. 228: 201-17.

Hayreh, SS; Klugman, MR; Podhajsky, P, et al (1990b). Argon laser panretinal photocoagulation in ischemic central retinal vein occlusion. A 10-year prospective study. Graefes Arch Clin Exp Ophthalmol. 228: 281-96.

Hayreh, SS (2007). Neovascular glaucoma. Prog Retin Eye Res. 26: 470-85.

Hjelmeland, LM; Steward, MW; Li, J; Toth, CA; Burns, MS; Landers, MB (1992). An experimental model of ectropion uveae and iris neovascularization in the cat. Invest Ophthalmol Vis Sci. 33: 1796-1803.

Hong, CH; Arosemena, A; Zurakowski, D; Ayyala, RS (2005). Glaucoma drainage devices: a systematic literature review and current controversies. Surv Ophthalmol. 50: 48-60.

Husain, D; Miller, JW; Kenney, AG; Michaud, N; Flotte, TJ; Gragoudas, ES (1997). Photodynamic therapy and digital angiography of experimental iris neovascularization using liposomal benzoporphyrin derivative. Ophthalmology. 104: 1242-50.

Hykin, PG; Shields, CL; Shields, JA; Arevalo, JF (1998). The efficacy of focal laser therapy in radiation-induced macular edema. Ophthalmology. 105: 1425-9.

Hyung, SM; Kim, SK (2001). Mid-term effects of trabeculectomy with mitomycin C in neovascular glaucoma patients. Korean J Ophthalmol. 15: 98-106.

Iliev, ME; Domig, D; Wolf-Schnurrbursch; Wolf, S; Sarra, GM (2006). Intravitreal bevacizumab (Avastin) in the treatment of neovascular glaucoma. Am J Ophthalmol. 142: 1054-6.

Iliev, ME; Gerber, S (2007). Long-term outcome of transscleral diode laser cyclophotocoagulation in refractory glaucoma. Br J Ophthalmol. 91: 1631-5. 
Ishibashi, S; Tawara, A; Sohma, R; Kubota, T; Toh, N (2010). Angiographic changes in iris and iridocorneal angle neovascularization after intravitreal bevacizumab injection. Arch Ophthalmol. 128: 1539-45.

Oguri, A; Takahashi, E; Tomita, G. Et al (1998). Transscleral cyclophotocoagulation with the diode laser for neovascular glaucoma. Ophthalmic Surg Lasers. 29: 722-7.

Ohrt, V (1961). Glaucoma due to rubeosis iridis diabetica. Ophthalmologica. 142: 356-65.

Katz, GJ; Higginbotham, EJ; Lichter, PR, et al (1995). Mitomycin C versus 5-fluorouracil in high-risk glaucoma filtering surgery. Extended follow-up. Ophthalmology. 102: 1263-9.

Kim, DH; Park, CK; Ahn, MD (2003). Clinical results of Ahmed valve implantation in the aspects of complications. J Korean Ophthalmol Soc. 44: 888-95.

Kiuchi, Y; Sugimoto, R; Nakae, K, et al (2006). Trabeculectomy with mitomycin C for treatment of neovascular glaucoma in diabetic patients. Ophthalmologica. 220: 383-8.

Kohno, RI; Hata, Y; Mochizuki, Y, et al (2010). Histopathology of neovascular tissue from eyes with proliferative diabetic retinopathy after intravitreal bevacizumab injection. Am J Ophthalmol. 150: 223-9.

Kotecha, A; Spratt, A; Ogunbowale, L, et al (2011). Intravitreal bevacizumab in refractory neovascular glaucoma: a prospective, observational case series. Arch Ophthalmol. 129: $145-50$.

Krishna, R; Godfrey, DG; Budenz, DL (2001). Intermediate-term outcomes of 350-mm² Baerveldt glaucoma implants. Ophthalmology. 108: 621-626.

Kubota, T; Tawara, A; Hata, Y, et al (1996). Neovascular tissue in the intertrabecular spaces in eyes with neovascular glaucoma. Br J Ophthalmol. 80: 750-4.

Laatikainen, L (1979). Development and classification of rubeosis iridis in diabetic eye disease. Br J Ophthalmol. 63: 150-6.

Lappin, MR; Dow, SW; Reif, JS; Chavkin, MJ (1997). Elevated interleukin-6 activity in aqueous humor of cats with uveitis. Vet Immunol Immunopathol. 58: 17-26.

Lee, J; Logani, S; Lakosha, H, et al (2001). Preretinal neovascularisation associated with choroidal melanoma. Br J Ophthalmol. 85: 1309-12.

Leszczynski, R; Domanski, R; Forminska-Kapuscik, M; Mrukwa-Kominek, E; Rokita-Wala, I (2009). Contact transscleral cyclophotocoagulation in the treatment of neovascular glaucoma: a five-year follow up. Medical Science Monitor. 15: BR84-7.

Li, Z; Van Bergen, T; Van de Veire, S, et al (2009). Inhibition of vascular endothelial growth factor reduces scar formation after glaucoma filtration surgery. Invest Ophthalmol Vis Sci. 50: 5217-25.

Lloyd, MA; Heuer, DK; Baerveldt, G, et al (1991). Combined Molteno implantation and pars plana vitrectomy for neovascular glaucomas. Ophthalmology. 98: 1401-5.

Luttrull, JK; Avery, RL (1995). Pars plans implant and vitrectomy for treatment of neovascular glaucoma. Retina. 15: 379-87.

Magargal, LE; Brown, GC; Augsburger, JJ; Donoso, LA (1982). Efficacy of panretinal photocoagulation in preventing neovascular glaucoma following ischemic central retinal vein obstruction. Ophthalmology. 89: 780-4.

Malecaze, F; Clamens, S; Simorre-Pinatel, V, et al (1994). Detection of vascular endothelial growth factor mRNA and vascular endothelial growth factor-like activity in proliferative diabetic retinopathy. Arch Ophthalmol. 112: 1476-82. 
Mason, JO; Nixon, PA; White, MF (2006). Intravitreal injection of bevacizumab (Avastin) as adjunctive treatment of proliferative diabetic retinopathy. Am. J. Ophthalmol. 142: 685-8.

Mason, JO; Albert, MA Jr; Mays, A, et al (2006b). Regression of neovascular iris vessels by intravitreal injection of bevacizumab. Retina. 26: 839-41.

Mermoud, A; Salmon, JF; Alexander, P; Staker, C; Murray, AD (1993). Molteno tube implantation for neovascular glaucoma: long-term results and factors influencing the outcome. Ophthalmology. 100: 897-902.

Mietz, H; Raschka, B; Krieglstein, GK (1999). Risk factors for failures of trabeculectomies performed without antimetabolites. Br J Ophthalmol. 83: 814-21.

Miller, H; Miller, B; Zonis, S; Nir, I (1984). Diabetic neovascularization: permeability and ultrastructure. Invest Ophthalmol Vis Sci. 25: 1338-42.

Miller, JW; Stinson, WG; Gregory, WA; el-Koumy, HA; Puliafito, CA (1991). Phthalocyanine photodynamic therapy of experimental iris neovascularization. Ophthalmology. 98: 1711-9.

Mizener, JB; Podhajsky, P; Hayreh, SS (1997). Ocular ischemic syndrome. Ophthalmology. 104: 859-64.

Moraczewski, AL; Lee, RK; Palmberg, PF; Rosenfeld, PJ; Feuer, WJ (2009). Outcomes of treatment of neovascular glaucoma with intravitreal bevacizumab. Br J Ophthalmol. 93: 589-93.

Murphy, CC; Burnett, CA; Spry, PG, et al (2003). A two centre study of the dose-response relation for transscleral diode laser cyclophotocoagulation in refractory glaucoma. Br J Ophthalmol. 87: 1252-7.

Netland, PA (2009). The Ahmed glaucoma valve in neovascular glaucoma (an AOS thesis). Transactions of the American Ophthalmological Society. 107: 325-42.

Nissen, N; Polverini, PJ \& Koch, AE (1998). Vascular endothelial growth factor mediates angiogenic activity during the proliferative phase of wound healing. Am J Pathol. 152: 1445-1452.

Norose, K; Yano, A; Wang, XC, et al (1994). Dominance of activated T cells and interleukin-6 in aqueous humor in Vogt-Koyanagi-Harada disease. Invest Ophthalmol Vis Sci. 35: 33-9.

Noureddin, BN; Zein, W; Haddad, C, et al (2006). Diode laser transcleral cyclophotocoagulation for refractory glaucoma: a 1 year follow-up of patients treated using an aggressive protocol. Eye. 20: 329-35.

Ohnishi, Y; Ishibashi, T; Sagawa, T (1994). Fluorescein gonioangiography in diabetic neovascularisation. Graefes Arch Clin Exp Ophthalmol. 232: 199-204.

Oshima, Y; Sakaguchi, H; Gomi, F; Tano, Y (2006). Regression of iris neovascularization after intravitreal injection of bevacizumab in patients with proliferative diabetic retinopathy. Am J Ophthalmol. 142: 155-8.

Packer, AJ; Tse, DT; Gu, XQ; Hayreh, SS (1984). Hematoporphyrin photoradiation therapy for iris neovascularization. Arch Opthalmol. 102: 1193-7.

Parodi, MB; Iacono, P (2004). Photodynamic therapy with verteporfin for anterior segment neovascularizations in neovascular glaucoma. Am J Ophthalmol. 138: 157-8. 
Parodi, MB; Iacono, P (2005). Photodynamic therapy for neovascular glaucoma. Ophthalmology. 112: 1844-5.

Parodi, MB; Friberg, TR; Pedio, M; Fiotti, N; Di Stefano, G; Ravalico, G (2007). Panretinal photocoagulationand photodynamic therapy for anterior segment neovascularization secondary to ischaemic central retinal vein occlusion. Ophthalmic Surg Lasers Imaging. 38: 94-9.

Pe'er, J; Neufeld, M; Baras, M; Gnessin, H; Itin, A; Keshet, E (1997). Rubeosis iridis in retinoblastoma. Histologic findings and the possible role of vascular endothelial growth factor in its induction. Ophthalmology. 104: 1251-8.

Perry, HD; Yanoff, M; Scheie, HG (1975). Rubeosis in Fuch's heterochromic iridocyclitis. Arch Ophthalmol. 93: 337-9.

Rehak, J; Vymazal, M (1994). Cryotherapy in treatment of neovascular glaucoma with closed chamber angle. Klin Monatsbl Augenheikd. 204: 20-3.

Rice, TA; Michels, RG; Maguire, MG; Rice, EF (1983). The effect of lensectomy on the incidence of iris neovascularization and neovascular glaucoma after vitrectomy for diabetic retinopathy. Am J Ophthalmol. 95: 1-11.

Rosendeld, PJ, Flynn Jr, HW; McDonald, HR, et al (1998). Outcomes of vitreoretinal surgery in patients with X-linked retinoschisis. Ophthalmic Surg Lasers. 29: 190-7.

Rush, R (2009). Ciliary sulcus Ahmed glaucoma valve tube placement in neovascular glaucoma. Ophthalmic Surg Lasers Imaging. 40: 489-92.

Saito, Y; Higashide, T; Takeda, H; Ohkubo, S; Sugiyama, K (2010). Beneficial effects of preoperative intravitreal bevacizumab on trabeculectomy outcomes in neovascular glaucoma. Acta Ophthalmologica. 88: 96-102.

Salmon, JF; Ursell, PG; Frith, P (2000). Neovascular glaucoma as a complication of retinal vasculitis in Crohn disease. Am J Ophthalmol. 130: 528-30.

Saunders, RA, et al (1994). Anterior segment ischemia after strabismus surgery. Surv Ophthalmol. 38: 456-66.

Sautter, H; Demeler, U (1984). Antiglaucomatous ciliary body excision. Am J Ophthalmol. 98: 344-8.

Schalenbourg, A; Coupland, S; Kacperek, A; Damato, B (2008). Iridocyclectomy for neovascular glaucoma caused by proton-beam radiotherapy of pigmented ciliary adenocarcinoma. Graefes Arch Clin Exp Ophthalmol. 246: 1499-1501.

Sheha, H; Kheirkhah, A; Taha, H (2008). Amniotic membrane transplantation in trabeculectomy with mitomycin C for refractory glaucoma. J Glaucoma. 17: 303-7.

Shen, SY; Lai, JS; Lam DS (2004). Necrotizing scleritis following diode laser transscleral cyclophotocoagulation. Ophthalmic Surg. Lasers Imaging. 35: 251-3.

Shields, CL; Zahler, J, Falk, N, et al (2007). Neovascular glaucoma from advanced Coats disease as the initial manifestation of facioscapulohumeral dystrophy in a 2-yearold child. Arch Ophthalmol. 125: 840-2.

Shields, JA; Shields, CL; Honavar, SG; Demirci, H (2001). Clinical variations and complications of Coats disease in 150 cases: the 2000 Sanford Gifford Memorial lecture. Am J Ophthalmol. 131: 561-71.

Sidoti, PA; Dunphy, TR; Baerveldt, G, et al (1995). Experience with the Baerveldt glaucoma implant in treating neovascular glaucoma. Ophthalmology. 102: 1107-18. 
Silva, PJ; Jorge, R; Alves Costa, R; et al (2006). Short-term results of intravitreal bevacizumab (Avastin) on anterior segment neovascularization in neovascular glaucoma. Acta Ophthalmol Scand. 84: 556-7.

Simmons, RJ; Deppermann, SR; Dueker, DK (1980). The role of goniophotocoagulation in neovascularization of the anterior chamber angle. Ophthalmology. 87: 79-82.

Sisto, D; Vetrugno, M; Trabucco, T; Cantatore, F; Ruggeri, G; Sborgia, C (2007). The role of antimetabolites in filtration surgery for neovascular glaucoma: intermediate-term follow-up. Acta Ophthalmol Scand. 85: 267-71.

Sivak-Callcott, JA; O'Day, DM; Gass, DM; Tsai, JC (2001). Evidence-based recommendations for the diagnosis and treatment of neovascular glaucoma. Ophthalmology. 108: 176776.

Skuta, GL; Beeson, CC; Higginbotham, EJ, et al (1992). Intra-operative mitomycin versus postoperative 5-fluorouracil in high risk glaucoma filtering surgery. Ophthalmology. 99: 438-44.

Spiteri Cornish K, Ramamurthi S, Saidkasimova S, Ramaesh K. (2009) Intravitreal bevacizumab and augmented trabeculectomy for neovascular glaucoma in young diabetic patients. Eye 4: 979-81

Takihara, Y; Inatani, M; Fukushima, M; Iwao, K; Iwao, M; Tanihara, H (2009). Trabeculectomy with mitomycin $\mathrm{C}$ for neovascular glaucoma: prognostic factors for surgical failure. Am J Ophthalmol. 147: 912-8.

Teich, SA; Walsh, JB (1981). A grading system for iris neovascularization. Am Acad Ophthalmol. 1102-6.

Telander, DG; Holland, GN; Wax, MB; Van Gelder, RN (2006). Rubeosis and anterior segment ischemia associated with systemic cryoglobulinemia. Am J Ophthalmol. 142: 689-90.

The CRVO Study Group (1993). Baseline and early natural history report. The Central Vein Occlusion Study. Arch Ophthalmol. 11: 1087-95.

The CRVO Study Group (1995). A randomized clinical trial of early panretinal photocoagulation for ischemic central vein occlusion. The Central Vein Occlusion Study Group N report. Ophthalmology. 102: 1434-4.

The Diabetes Control and Complications Trial Research Group (1993). The Effect of Intensive Treatment of Diabetes on the Development and Progression of LongTerm Complications in Insulin-Dependent Diabetes Mellitus. N Engl J Med. 329977-86.

Tsail, JC; Feuer, WJ; Parrish, RK 2nd; Grajewski, AL (1995). 5-Fluorouracil filtering surgery and neovascular glaucoma. Long-term follow-up of the original pilot study. Ophthalmology. 102: 887-92.

Vote, B; Fuller, JR; Bevin, TH; Molteno, AC (2004). Systemic anti-inflammatory fibrosis suppression in threatened trabeculectomy failure. Clin Experiment Ophthalmol. 32: 81-6.

Wakabayashi, T; Oshima, Y; Sakaguchi, H, et al (2008). Intravitreal bevacizumab to treat iris neovascularization and neovascular glaucoma secondary to ischemic retinal diseases in 41 consecutive cases. Ophthalmology. 115: 1571-80. 
Weiss, DI, Gold, D (1978). Neovascularization of iris and anterior chamber angle: a clinical classification. Ann Ophthalmol. 10: 488-91.

Wen, JC; McCannel, TA (2009). Treatment of radiation retinopathy following plaque brachytherapy for choroidal melanoma. Curr Opin Ophthalmol. 20: 200-4.

Wilgus, TA; Ferreira, AM; Oberyszyn, TM, et al (2008). Regulation of scar formation by vascular endothelial growth factor. Lab Invest. 88: 579-90.

Williams, JM Sr; de Juan Jr, E; Machemer, R (1988). Ultrastructural characteristics of new vessels in proliferative diabetic retinopathy. Am J Ophthalmol. 105: 491-9.

Yalvac, IS; Eksioglu, U; Satana, B; Duman, S (2007). Long-term results of Ahmed glaucoma valve and Molteno implant in neovascular glaucoma. Eye. 21: 65-70.

Yap-Veloso, MI; Simmons, RB; Echelman, DA; Gonzalez, TK; Veira, WJ; Simmmons, RJ (1998). Intraocular pressure control after contact transscleral diode cyclophotocoagulation in eyes with intractable glaucoma. J Glaucoma. 7: 319-28.

Yeung, SN; Paton, KE; Waite, C; Maberley, DA (2010). Intravitreal bevacizumab for iris neovascularization following proton beam irradiation for choroidal melanoma. Canadian J Ophthalm. 45: 269-73.

Yildirim, N; Yalvac, IS; Sahin A; Ozer, A; Bozca, T (2009). A comparative study between diode laser cyclophotocoagulation and $\mathrm{t}$ Ahmed glaucoma valve implant in neovascular glaucoma: a long-term follow-up. J Glaucoma. 18: 192-6.

$\mathrm{Yu}, \mathrm{XB}$; Sun, XH; Dahan, E, et al (2007). Increased levels of transforming growth factor-beta1 and beta2 in the aqueous humor of patients with neovascular glaucoma. Ophthalmic Surg Lasers Imaging. 38: 6-14. 


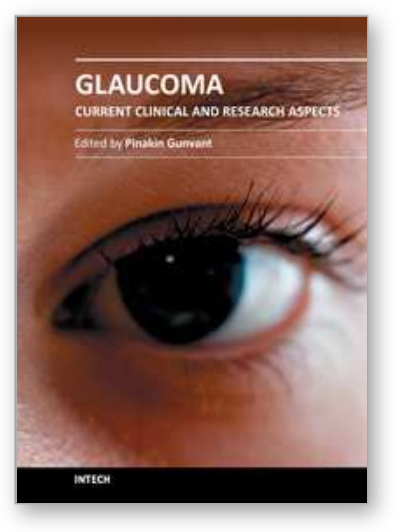

\author{
Glaucoma - Current Clinical and Research Aspects \\ Edited by Dr. Pinakin Gunvant
}

ISBN 978-953-307-263-0

Hard cover, 376 pages

Publisher InTech

Published online 09, November, 2011

Published in print edition November, 2011

This book summarizes current literature about research and clinical science in glaucoma and it is a synopsis and translation of the research conducted by individuals who are known in each of their respective areas. The book is divided into two broad sections: basic science and clinical science. The basic science section examines bench- and animal-modeling research in an attempt to understand the pathogenesis of glaucoma. The clinical science section addresses various diagnostic issues and the medical, laser and surgical techniques used in glaucoma management.

\title{
How to reference
}

In order to correctly reference this scholarly work, feel free to copy and paste the following:

Kurt Spiteri Cornish (2011). Neovascular Glaucoma, Glaucoma - Current Clinical and Research Aspects, Dr. Pinakin Gunvant (Ed.), ISBN: 978-953-307-263-0, InTech, Available from:

http://www.intechopen.com/books/glaucoma-current-clinical-and-research-aspects/neovascular-glaucoma

\section{INTECH}

open science | open minds

\section{InTech Europe}

University Campus STeP Ri

Slavka Krautzeka 83/A

51000 Rijeka, Croatia

Phone: +385 (51) 770447

Fax: +385 (51) 686166

www.intechopen.com

\section{InTech China}

Unit 405, Office Block, Hotel Equatorial Shanghai

No.65, Yan An Road (West), Shanghai, 200040, China

中国上海市延安西路65号上海国际贵都大饭店办公楼 405 单元

Phone: +86-21-62489820

Fax: $+86-21-62489821$ 
(C) 2011 The Author(s). Licensee IntechOpen. This is an open access article distributed under the terms of the Creative Commons Attribution 3.0 License, which permits unrestricted use, distribution, and reproduction in any medium, provided the original work is properly cited. 